\title{
The Concept of Freedom in Judaism, Christianity and Islam,
}

edited by Georges Tamer and Ursula Männle (Berlin/Boston: Walter de Gruyter, 2019), viii+168 pp., ISBN 9783110560558, €25.95 (pb)

I have to confess that, when I first came across this book, I was somewhat wary of what I would find between the covers of this slim volume. For the past couple of centuries, a particular conception of freedom became the universal benchmark against which all other conceptions had to be measured, and if they were not the same as the only one admissible, well, they were not really conceptions of freedom.

On the one hand, this conception is intertwined with the so-called liberal democracy [for Carl Schmitt (1888-1985), a contradiction in terms] and market economy, which, in turn, are themselves particular forms of democracy and economy elevated to the category of universal ones, including in the academic world, which is supposed to be the realm of scientific and objective enquiry (but that is another matter), despite the fact that the practice of some of its apologists led to the unfreedom of several parts of the world. On the other hand, and despite its religious overtones, or because of it, this conception of freedom sees religion as one of its enemies, not to say the enemy, considered as a fortress of irrationality, darkness, and servitude (whatever these may mean).

Usually, works dealing with issues such as "Judaism," "Christianity" and, especially, "Islam" are always prone to vapid, sweeping generalizations ("Judaism and Islam are religions of law" or "Christianity separates church and state"), and, instead of being descriptive, they are prescriptive, not being unusual to read, or hear, old-chestnuts such as "Islam needs an urgent reform similar to that which occurred during the Christian Reformation..." (If we are going to accept linear time and "Western" history as the models, then by the $20^{\text {th }}$ Hijri century "Islam" will finally have its own concentration camps and gas chambers...) 
As Ellen Meiksins Wood (1942-2016) reminded us, there has been much confusion about Islam and the consequences of its belief in a single divinely revealed system of law, encompassing the whole range of human practice, secular as well as religious. We have become familiar with a strain of Islam, for which this view of the law requires an "Islamist" state, replacing secular governance with a so-called "fundamentalist theocracy." But this was certainly not characteristic of Islam in the medieval and early modern periods. The belief in a single divinely revealed law meant not the dominance of mullahs but, on the contrary, the absence of an institutional power comparable to the Christian ecclesiastical establishment, with its own distinct claims to authority and obedience. There was no autonomous Islamic power such as the Catholic Church for policing theology, let alone laying claim to authority over the whole temporal domain. There were no jurisdictional claims and disputes of the kind that characterized Christianity; and this permitted, among other things, an openness to the idea that truth could be arrived at in various ways - for example, by means of secular philosophy no less than by means of Islamic theology. By the same reasoning, a secular government could be perfectly consistent with Islamic theology - and perhaps without all the tensions engendered by jurisdictional conflicts of Western Christianity. Christian theology did not prevent secular governments from claiming their authority as divinely ordained; and, if anything, the jurisdictional dualism of Christianity could easily accommodate, indeed invite, a doctrine of strict obedience to secular authority imposed on sinful human beings, in the manner of Saint Augustine (354-430) and Martin Luther (1483-1546).

So, when I read the back cover of the book under review, my expectations became high. This volume, the third in the Key Concepts in Interreligious Discourses series, but the first to be published, is divided into five parts: a Preface by the editors, three chapters on the concept of freedom in, respectively, Judaism (pp. 1-44), Christianity (pp. 45-100) and Islam (101-146), and, finally, an Epilogue (pp. 147158). Its main aim is to investigate the roots of the concept of freedom in Judaism, Christianity and Islam and its relevance for the present time. The idea of freedom in terms of personal freedoms, which include freedom of conscience, freedom of speech and bodily integrity, is a relatively new one and can in some aspects get into conflict with religious convictions. At the same time, freedom as an emancipatory power from outer oppression as well as from inner 
dependencies is deeply rooted in Judaism, Christianity and Islam. It is still a vital concept in religious and non-religious communities and movements. The volume presents the concept of freedom in its different aspects as anchored in the traditions of Judaism, Christianity and Islam, and unfolds commonalities and differences between the three monotheistic religions as well as the manifold discourses about freedom within these three traditions. All the chapters have introductory remarks, a conclusion, bibliography, and suggestions for further reading, but my expectations were not met.

The first chapter, by Kenneth Seeskin, is less about freedom in Judaism than personal reflections about some issues, more or less interlocked with that concept. The chapter is divided into five sections (The Giving of Law; Sabbath Observance; Repentance; Freedom of Thought; and Messianism), and draws heavily on previous works by the author, who is a Professor of Jewish Civilization, and best known for his interpretation and defense of the rationalist tradition in Jewish Philosophy, including such figures as Maimonides (113?-1204), Spinoza (1632-1677), and Hermann Cohen (1842-1918).

The chapter on Christianity by Nico Vorster is very well structured and organized, and should have been used as a template for the other two chapters. It was the chapter I enjoyed the most and it starts with basic Biblical terminology and essential theological and philosophical features. Then, it gives the reader the historical development of the Christian concepts of freedom, showing us that there are several concepts and not just one. In a fourth sub-chapter, the author refers to the main differences between contemporary Catholic, Protestant and Orthodox approaches to freedom, and the last two parts of the chapter are about the current use and impact of the concept of freedom within Christianity, and the practical application and future relevance of the Christian concept of freedom. There is also a sub-chapter, the fifth, on Christian concepts of freedom in relation to Judaism and Islam, which felt like an exercise in Christian intellectual imperialism - that comparison is not made by the other two authors and that task should have been the monopoly of the editors of the volume.

The chapter on Islam is by Maha El Kaisy-Friemuth. The author starts by referring to the perception of freedom in pre-Islamic Arabic culture and in the Qur'ān, and to the concept of freedom in Islamic theology. A reader not acquainted with Islamic history will not have the faintest idea of what or who the author is talking about, since no dates and no historical contextualization are given. The next two sub- 
chapters deal with freedom and individuality among the Muslim philosophers, and the Sufis and their concept of freedom. For this, the only sources that the author uses are Ibn Sinnā [Avicenna (980-1037)] and al-Ghazālī (1058-1111): where are Ibn Bājjah [Avempace (10851138)], Ibn Țufayl (1105-1185), Ibn Rushd [Averroes (1126-1198)], the Ismācīlī thinkers, Farīd al-Dīn 'Ațtāā (1145-1221), Ibn 'Arabī (11651240), Jalāl al-Dīn Rūmī (1207-1273),...? And then, as if nothing had happened during seven and a half centuries, the author jumps from alGhazālī directly to al-Afghānī (1838-1897): it seems that no one thought about freedom in the Ottoman Empire, in Safavid Iran, in Mughal India, in the Malay world, in sub-Saharan Africa... Not even Ibn Khaldūn (1332-1406) is mentioned.

Considering that there were no references to women in the chapters about Judaism and Christianity, it was odd to read about freedom and the rights of women in Islam, as if there is something particular to Islam in what refers to women, perpetuating old stereotypes (One just needs to look at the numbers concerning gender and sexual violence, murders, and so on, in Jewish, Christian, and "secular" societies to see that there is nothing exceptional about "Islam").

Parts seven and eight are about freedom of belief and apostasy, and critical free thinking versus blind following. But the worst was still to come. In the ninth sub-chapter, about freedom in the Shī'a thought (if there is a section on Shī'a thought, where is the Sunnī counterpart? I have to assume that the author considers Sunni thought as the norm and, so, it does not need a separate section), Maha El Kaisy-Friemuth summarizes in one paragraph, less than six lines, a millennium of history and then, to give two examples of contemporary Shì' $\overline{1}$ thinkers, she refers to the Iranian Mohammad Mojtahed Shabestarī (b. 1936) and to the Irāqī Muhammad al-Bāqir al-Hakīm (1939-2003). El KaisyFriemuth also refers two of the books by the latter, Our Philosophy and Our Economy. The problem is that these two books are by Muhammad Bāqir al-Ṣadr (1935-1980), who was executed by the Irāqi regime. Although she cites his book Our Economy, she made a gross mistake by not noticing that they were two different persons. The final part, on freedom and its limitation, is clearly misplaced, since it deals with Islamic theology of the early days of Islam.

The book ends with an Epilogue, by Georges Tamer and Katja Thörner, where the reader finds a summary of the concepts of freedom from a Jewish, Christian, and Islamic perspective as well as common features and differences [one wonders why the authors did not use the 
term "Muslim" instead of "Islamic" - Maimonides was a Jewish thinker who worked and lived in an Islamic environment, and Edward Said (1935-2003) was born into a Christian family and he considered himself as being part of an Islamic culture]. Finally, the last section is about the confrontation with secular ideas of freedom in modernity.

The book series aims to bring together academic studies of essential concepts and discourses in Judaism, Christianity and Islam, offering a new approach to the study of these religions by investigating the original understandings and major developments of the central concepts responsible for shaping each one of these traditions, and aims to establish an archaeology of religious knowledge, which can enable a new understanding of religious concepts as evolving products of living discourses that emerge under diverse historical and cultural circumstances, creating a new conceptual platform capable of engendering further interreligious discourses and fruitful interreligious exchange. This is commendable and, in order to achieve these goals, it has to be defined a template followed by each and every author, whose quality, of course, should be paramount.

\section{Carimo Mohomed}

Catholic University, Lisbon-Portugal mohomed.carimo@gmail.com https://orcid.org/0000-0002-8205-4429 